\title{
МІЖНАРОДНА КОНКУРЕНТОСПРОМОЖНІСТЬ: РОЛЬ МАКРОЕКОНОМІЧНОЇ СТАБІЛЬНОСТІ. ПІДПРИЄМНИЦЬКА ДІЯЛЬНІСТЬ В ГЛОБАЛЬНІЙ ЕКОНОМІЦІ
}

\section{INTERNATIONAL COMPETITIVENESS: THE ROLE OF MACROECONOMIC STABILITY. ENTREPRENEURIAL ACTIVITY IN THE GLOBAL ECONOMY}

\author{
Кім Тетяна Іванівна \\ кандидат економічних наук, доцент, \\ Харківський національний університет імені В.Н. Каразіна \\ ORCID: https://orcid.org/0000-0003-3825-2564 \\ Кім Олексій Олексійович \\ кандидат економічних наук, \\ Харківський національний університет імені В.Н. Каразіна \\ ORCID: https://orcid.org/0000-0003-3851-1626 \\ Kim Tetiana, Kim Oleksii \\ V.N. Karazin Kharkiv University
}

\begin{abstract}
Стаття присвячена актуальному дослідженню ролі малого і середнього бізнесу в умовах фрормування єдиного світогосподарського простору. На основі аналізу частки зайнятих на підприємствах малого, середнього та великого бізнесу в світовій економіці у розрізі геограсрічних регіонів світу та відповідно до груп країн за рівнем середньодушового ВНД, а також аналізу внеску в додану вартість цих підприємств доведено зростання ролі малого та середнього бізнесу, що об'єктивно обумовлене діючими фракторами. Показані розбіжності в розвитку ссрери малого та середнього бізнесу по регіонах і доходних групах країн, обумовлені впливом технологічного, організаційного та інституційного розвитку. Охарактеризовано суб'єктивні передумови розвитку підприємницької активності, визначено перспективи розвитку різних форм і зростання ефрективності підприємств малого та середнього бізнесу.

Ключові слова: глобальна економіка, підприємницька діяльність, міжнародна конкурентоспроможність, макроекономічна стабільність, особливості МСБ в групах країн.
\end{abstract}

Статья посвящена актуальному исследованию роли малого и среднего бизнеса в условиях фрормирования единого мирохозяйственного пространства. На основе анализа долей занятых на предприятиях малого, среднего и крупного бизнеса в мировой экономике в разрезе географических регионов мира и в соответствии с группами стран по уровню среднедушевого ВНД, а также анализа вклада в добавленную стоимость этих предприятий доказан рост роли малого и среднего бизнеса, что объективно обусловлено действующими фракторами. Показаны различия в развитии сферы МСБ по регионам и доходным группам стран, обусловленные влиянием технологического, организационного и институционального фракторов. Охарактеризованы субъективные предпосылки развития предпринимательской активности, определены перспективы развития разных фрорм и повышения эффрективности предприятий МСБ.

Ключевые слова: глобальная экономика, предпринимательская деятельность, международная конкурентоспособность, макроэкономическая стабильность, особенности МСБ в группах стран.

The article is devoted to the actual study of the role of small and medium-sized businesses in the conditions of the formation of a global economic system. The methodology is based on the analysis of the shares of people employed in small, medium and large businesses in the global economy in terms of geographical regions of the world and in accordance with groups of countries by the level of per capita GNI. Also an analysis of the contribution to the value added of these enterprises, the growth of the role of small and medium businesses is proved, which objectively 
conditioned by the factors of macroeconomic stability. Differences in the development of the SME sector by regions and income groups of countries are shown, due to the influence of technological, organizational and institutional factors. The subjective prerequisites for the development of entrepreneurial activity are characterized, the prospects for the development of various forms and increasing the efficiency of SMEs are determined. In the process of forming a global economy the role of small and medium-sized businesses is strengthening, increasing its economic efficiency and social significance as a factor in the level and quality of life. Depending on the level of socio-economic development in countries there is a different ratio of forms of SMEs: the lower the level of development of the country (per capita income), the greater the share of self-employed in micro and small enterprises, the lower business efficiency and lower contribution to added value of the country. In the conditions of post-industrialization of the world economy, an introduction of digital technologies increases the role of the SME sphere through its involvement in the process of innovative development. The role of SMEs in increasing the welfare of the population, the development of labor potential and economic activity of both the individual and society as a whole is growing, which provides an opportunity for sustainable economic and social development. SMEs have become especially important in developed countries, which purposefully create a favorable institutional environment to stimulate economic activity in the domestic market with a prospects of entering the world market.

Keywords: global economy, entrepreneurial activity, international competitiveness, macroeconomic stability, SMEs features in groups of countries.

Постановка проблеми у загальному вигляді. Дослідження ролі малого і середнього бізнесу в сучасній глобальній економіці обумовлена важливістю його як фрактору економічного зростання і стабільності, інноваційної здібності, так і сорери життєдіяльності та соціальних можливостей людей. У швидко змінному економічному просторі кожній особистості потрібне чітке розуміння можливостей і фрорм самореалізації, що базується на знанні сучасних тенденцій в структурі економічних процесів, зокрема в бізнес-середовищі. У цьому дослідженні термін «бізнес» змістовно означає економічну діяльність людини у будь-якій сорері - виробничій, комерційній, фрінансовій, соціальній, тощо. Тобто термін малий та середній бізнес виступає широким поняттям, що включає і інноваційну підприємницьку діяльність, і реплікативну (повторювану, копіювальну) діяльність за різних правових умов (самостійний незалежний бізнес або за угодою франчайзингу, лізингу тощо), навіть, неприбуткову соціальну діяльність. Метою бізнесу як цілеспрямованої діяльності фрізичної або юридичної особи зазвичай є отримання економічного ефректу прибутку, але в сучасному світі метою бізнесу можуть виступати інші ефректи - створення соціальної, культурної цінності, досягнення екологічного есректу, просування на більш високий щабель технологічного, організаційно-економічного розвитку тощо. Отже в нашому розумінні поняття бізнес узагальнюється діяльністю, яка спрямована на досягнення економічного, соціального (соціальнопсихологічного) та екологічного ефектів, що мають прогресивне значення для особистості бізнесмена, громади, суспільства, регіону, країни та світової економіки в цілому.
Аналіз останніх досліджень і публікацій. Дослідженню наукової проблеми розвитку малого та середнього бізнесу в сучасному світі присвячені праці таких авторів, як Гой I., Педько А., Смелянська Т., Дахно І., АлієваБарановська В., Шнирков О., Руденко І. В. та ін. В роботах цих авторів представлені поняття і визначення сутності, класифрікації, методи кількісного і якісного аналізу МСБ на різних рівнях економічного простору - локального, регіонального, національного тощо, розглянуті проблеми інституційного середовища розвитку бізнесу і підприємництва, внутрішні і зовнішні фоктори розвитку тощо. Значну дослідницьку діяльність на основі моніторингу структурних складових глобального бізнесу здійснюють експерти Міжнародної організації праці та Організації об'єднаних націй з питань сталого економічного розвитку.

Виділення не вирішених раніше частин загальної проблеми. Наше дослідження присвячене узагальненню особливостей розвитку сектору МСБ на глобальному рівні, в масштабах світових географрічних регіонів та у групах країн світу згідно з типологією за рівнем доходу на душу населення, а також виявленню сутнісних змін у структурі бізнесу за розміром підприємств, оцінці ролі малого i середнього бізнесу в глобальному світогосподарському просторі, обумовлених фрактором макроекономічної стабільності.

Формулювання цілей статті (постановка завдання). Метою статті $€$ на основі аналізу макроекономічних чинників визначити тенденції розвитку міжнародної конкурентоспроможності підприємницької діяльності, зокрема оцінити роль сектору малого та середнього бізнесу в глобальній економіці в цілому, за регіонами та доходними групами 
країн світу, оцінити вплив фрактору макроекономічної стабільності на цей сектор.

Виклад основного матеріалу дослідження. Світова економіка як складна розгалужена багаторівнева ієрархічна система $\epsilon$ історичною і політико-економічною категорією. Ії̈ суб'єктами виступають національні господарства, міжнародні інтеграційні об'єднання, транснаціональні компанії, міжнародні організації. За рівнем і темпами соціально-економічного розвитку країни світу дуже розрізняються одна від одної, і розшарування з часом лише зростає.

На сучасному етапі еволюції світової економіки, який іменують транснаціональним через інтернаціоналізацію усіх фрорм руху капіталу - грошової, виробничої, товарної, відбувається перетворення світової економіки на єдиний всесвітній (наднаціональний) світогосподарський простір (ЄСП). Формується наднаціональне світогосподарське середовище економічних процесів, зокрема, бізнесу, що регулюється єдиними економічними, технологічними, правовими і соціокультурними нормами і вимогами до діючих у цьому просторі суб'єктів - виробничих та комерційних компаній.

Процес орормування ЄСП розгортається під впливом таких фракторів, як: впровадження інформаційних технологій, закладення підвалин та розвиток соціально орієнтованих ринкових економічних систем на національному рівні, інтернаціоналізація правових норм та соціокультурних цінностей тощо.

Організаційно-економічну основу світової економіки складає двох-секторна система взаємодіючих підприємств великого і малого та середнього бізнесу. Великий бізнес забезпечує великомасштабне виробництво та дослідницько-розробницьку діяльність, малий та середній бізнес забезпечує насичення товарами і послугами у «нішах» ринку, сприяє зростанню зайнятості, доходів, добробуту населення, зростанню і розвитку економіки завдяки своїм характеристикам гнучкості, мобільності, адаптивності до змін.

В залежності від кількості працюючих підприємства розподіляються на малі економічні одиниці (самозайняті працівники та мікропідприємства), малі, середні та великі підприємства за класиорікацією Міжнародної організації праці [5], що більш детально відображає таблиця 1. В законодавствах різних країн класифрікація підприємств включає також критерії річного обороту та річного балансу. Роль сектору МСБ у світовій економіці можна оцінити за економічними (частка МСБ у доданій вартості, у зайнятості, у експорті тощо) та соціальними показниками (рівень доходів населення, якість життя тощо).

Значення сектору малого і середнього бізнесу в сучасному світі помітно збільшується під дією як внутрішніх, так і зовнішніх фракторів по відношенню до особистості суб'єкта МСБ. Внутрішнім фрактором, за нашою думкою, виступає зростаюча соціально-психологічна готовність, усвідомлення відповідальності особистості за самореалізацію та матеріально-фрінансове забезпечення власного життя, бажання прийняти виклик і випробувати власний потенціал діяльнісної активності в сучасному світі. Зовнішнім фрактором виступає макроекономічна стабільність за методикою ВЕФ [8].

Розвитку підприємництва сприяє розвиток інституційного середовища, технологічного і

Таблиця 1

Класифрікація категорій зайнятості та підприємств Міжнародної організації праці за розміром підприємств

\begin{tabular}{|l|l|l|}
\hline \multicolumn{2}{|c|}{ Термін } & \multicolumn{1}{c|}{ Визначення } \\
\hline \multirow{2}{*}{$\begin{array}{l}\text { Малі економічні } \\
\text { одиниці }\end{array}$} & Самозайняті & $\begin{array}{l}\text { Незалежні працівники без найманих працівників } \\
\text { (Резолюція МКСП 2018) } \\
\text { Особи, що працюють за власні кошти } \\
\text { (Резолюція МКС3*夫 1993) }\end{array}$ \\
\hline Малі підприємства & Мікропідприємства & 2-9 працівників \\
\hline $\begin{array}{l}\text { Середні } \\
\text { підприємства }\end{array}$ & 10-49 працівників & \\
\hline Великі підприємства & 250 та більше & \\
\hline
\end{tabular}

Джерело: створено автором за матеріалами [5]

*МКСП - Міжнародна конференція статистиків праці.

**МКСЗ - Міжнародна класифрікація статусу зайнятості. 
Таблиця 2

\section{Характерні риси сектору МСБ, що визначають його роль і місце в сучасній економічній системі}

\begin{tabular}{|c|c|c|}
\hline Цілі МСБ & Переваги МСБ & Обмеження МСБ \\
\hline $\begin{array}{l}\text { - задоволення потреб } \\
\text { населення і отримання } \\
\text { прибутку; } \\
\text { - підвищення добробуту } \\
\text { населення; } \\
\text { - сприяння } \\
\text { економічному зростанню } \\
\text { галузей, регіонів, країни; } \\
\text { - інноваційний розвиток; } \\
\text { - сталий економічний } \\
\text { розвиток на усіх рівнях. }\end{array}$ & $\begin{array}{l}\text { - близькість до клієнта, можливість } \\
\text { задовольняти індивідуальні потреби; } \\
\text { - здатність змінюватися, швидко } \\
\text { адаптуватися до змін; } \\
\text { - низькі управлінські витрати; } \\
\text { - «нішова» спеціалізація; } \\
\text { - інноваційність; } \\
\text { - мобільність та здатність } \\
\text { об'єднання заради підсилення } \\
\text { конкурентоспроможності; } \\
\text { - раціональне використання місцевих } \\
\text { ресурсів; } \\
\text { - здатність створювати робочі місця, } \\
\text { стабілізувати попит; } \\
\text { - здатність виробляти і насичувати } \\
\text { ринок товарами і послугами. }\end{array}$ & $\begin{array}{l}\text { - малий розмір капіталу; } \\
\text { - менша продуктивність } \\
\text { праці і нижча якість } \\
\text { продукції; } \\
\text { - нижчі доходи, ніж у } \\
\text { великих компаніях; } \\
\text { - слабкіший соціальний } \\
\text { захист; } \\
\text { - великі ризики втратити } \\
\text { дохід та збанкрутіти. }\end{array}$ \\
\hline
\end{tabular}

Джерело: складено авторами за даними [2; 6; 7]

людського потенціалу. Значні перспективи розвитку МСБ відмічаються у екологічній сфері, сорері соціальних, соціально-побутових, соціально-психологічних послуг. Ми вважаємо, що розширюються перспективи розвитку індивідуальних освітніх та просвітницьких послуг.

Роль і місце сектору малого та середнього бізнесу визначають його цільове призначення і характерні риси, що зумовлюють відповідні переваги і обмеження (таблиця 2).

Отже, на основі узагальнення цілей, переваг і обмежень фрункціонування МСБ можна оцінити перспективи його розвитку, як у напрямку зростання підприємницької (інноваційної) частки, так і у напрямку вдосконалення інституційної інфрраструктури як фрактору підвищення ефрективності МСБ і через неї - економічної сфери в цілому.

Роль сектору МСБ можливо оцінити за допомогою таких показників, як: частка підприємств МСБ у загальній чисельності підприємств; частка зайнятих у всіх типах підприємств МСБ порівняно з часткою зайнятих у великих компаніях; частка доданої вартості, створеної підприємствами МСБ; частка валового внутрішнього продукту (національного доходу), створеного підприємствами МСБ; частка експорту підприємств МСБ у експорті продукції або у загальному обсязі експорту; частка податків сектору МСБ; частки виробництва окремих видів продукції або послуг, вироблених підприємствами МСБ. На основі цих показників можна оцінити роль і вплив сектору малого та середнього бізнесу як у різних країнах 3 метою порівняння, так і узагаль- нити роль МСБ у світовій економіці. Найчастіше використовують визначення частки МСБ у зайнятості та у доданій вартості.

Для аналізу ролі МСБ у світовій економіці ми скористалися регіональним підходом та класифрікацією країн Світового банку, виявляючи частку зайнятості в секторі МСБ по регіонах світу та в групах країн за критерієм ВНД на душу населення. Джерелом статистичних даних $є$ Міжнародна організація праці (МОП).

За оцінками МОП, частка зайнятих в секторі МСБ сягає у світовому масштабі більше як $70 \%$, а в доданій вартості - більше $60 \%$. Структура зайнятих за розміром підприємств (згідно таблиці 1): 32\%:23,1\%:14,3\%:29,8\% [6]. Аналіз цих часток в регіональному розрізі та в розрізі країн світу за рівнем доходу показує значні варіювання як пропорцій між видами малого, середнього і великого бізнесу в регіонах та країнах, так і відповідних внесків у додану вартість.

Заради більш об'єктивного відображення реальності і можливості співставлення пропорцій між видами МСБ, МОП поєднує статистику середнього та великого бізнесу, а сектор малого бізнесу, навпаки, деталізує, адже у країнах, що розвиваються (населення яких становить 2/3 населення світу), найбільша частка зайнятих припадає саме на малі підприємства.

Рисунок 1 демонструє концентрацію зайнятого населення у різних секторах бізнесу за кількістю працюючих за регіонами світу. Найбільші частки самозайнятого населення спостерігаються в регіонах Південної Азії (66,5\%), 


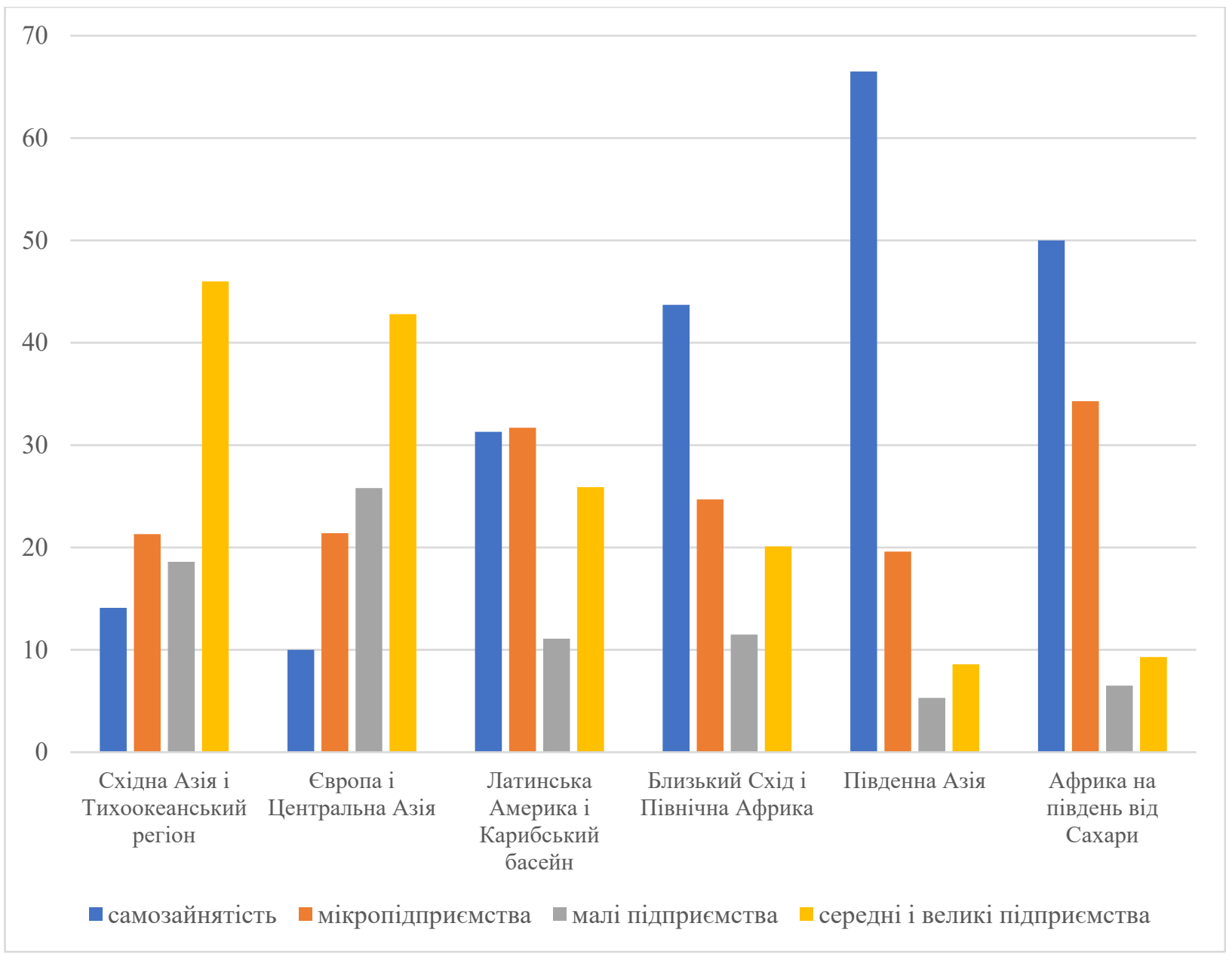

Рис. 1. Частки зайнятого населення на підприємствах за розміром за регіонами світу, \% Джерело: складено авторами за даними [6]

Афррики на південь від Сахари (50\%) та Близький Схід і Північна Асррика (43,7\%), найменша частка самозайнятих - в Європі та Центральній Азії (10\%). Найбільша частка зайнятих на мікропідприємствах спостерігається в регіоні Афррики на південь від Сахари (34\%), найменша - у Південній Азії (19,6\%). Найбільша частка зайнятих на малих підприємствах спостерігається у регіоні Європи та Центральної Азії (25,8\%), найменша - в Південній Азії (5,3\%). Найбільші частки зайнятих у секторі середнього та великого бізнесу характерні для Східної Азії і Тихоокеанського регіону (64\%) і Європи та Центральної Азії (42,8\%), найменша частка - У Південній Азії (8,6\%). Пояснюється ця ситуація відмінністю у чиннику макроекономічної стабільності - якщо в регіонах Європи, Північної Америки, Східної Азії та Океанії він високий, то в решті регіонів - низький [8], що сприяє самозайнятості.

Найбільша частка зайнятості у секторі підприємств з чисельністю працюючих менше
50 - 91,4\% належить регіону Південної Азії, 90,7\% - регіону Афррики на південь від Сахари, 79,9\% - регіону Близького Сходу і Північної Афррики, 74,1\% - регіону Латинської Америки і Карибського басейну, 57,2\% - регіону Європи та Центральної Азії, 54\% - регіону Східної Азії та Тихого океану. Частка зайнятих на середніх та великих підприємствах найбільша в більш економічно розвинених регіонах.

Завдяки використанню інформаційнокомп'ютерних технологій, зокрема інтернет-технологій, мережевих технологій у бізнес-процесах сектор малого та середнього бізнесу розвивається прискореними темпами через зростання інноваційного підприємництва (реклама, партнерство, продажі 3 оплатою через інтернет тощо). Відстають країни, що не володіють потенціалом технологічного розвитку, або регіони, що не мають мережі Інтернет. Також завдяки смарт-технологіям в розвинутих країнах стає більш комсоортним 


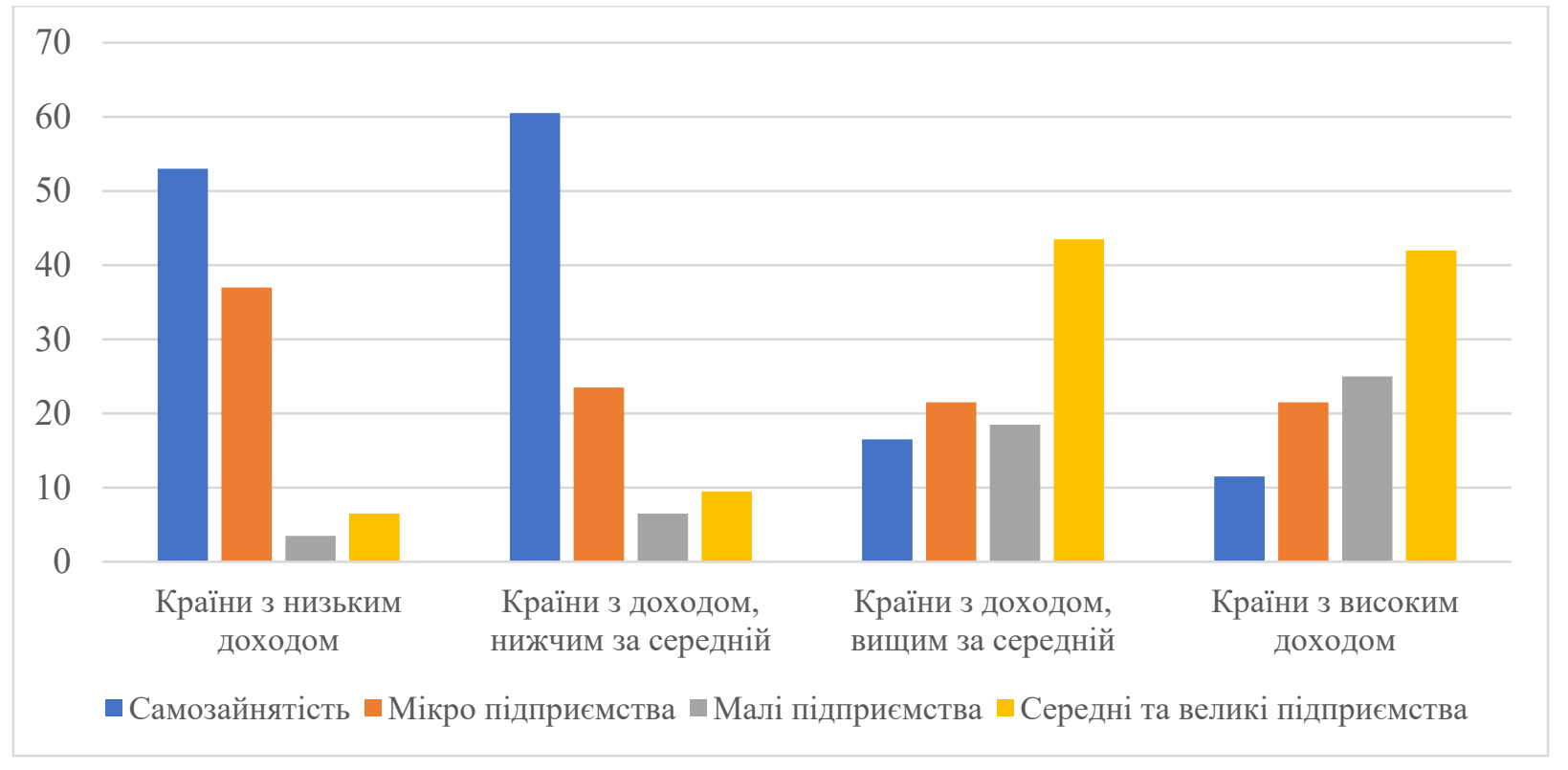

Рис. 2. Частки зайнятого населення на підприємствах малого, середнього та великого бізнесу за групами країн світу по ВНД на душу населення, \% Джерело: складено авторами за даними [6]

відкриття власної справи, здійснення комунікацій з клієнтами, партнерами, адмініструванням. Взагалі МСБ, зокрема, МСП - $є$ потужним фрактором підтримки і розповсюдження IКТ у світовій економіці.

Нерівномірність розвитку МСБ обумовлює розшарування світової бізнес-сорери за якістю робочих місць: самозайнятість, мікро- і малі підприємства найбільше поширені в бідних країнах і регіонах, але такі фрорми МСБ за більшістю не є інноваційними, а $є$ реплікативними, 3 низьким рівнем ефективності. Зайнятість на таких підприємствах малопродуктивна, малооплачувана, соціально незахищена, 3 нею пов'язане явище працюючої бідності, еквівалентної найманій праці з низькою заробітною платнею.

Аналіз даних на рисунку 2 вказує на те, що частка зайнятих у секторі малого бізнесу у вищій доходній групі країн складає від 40\% до $60 \%$ (рідше $70 \%$ ), у нижчій - сягає за $70 \%$ і в найменш розвинених країнах може доходити до $99 \%$ із переважанням самозайнятого населення. Найбільші частки самозайнятих, як і найвищі частки зайнятих на підприємствах, менших за середній розмір, спостерігаються в групах країн з низьким доходом та з доходом, нижчим за середній. Найбільші частки зайнятих на підприємствах із кількістю працівників 50 і більше спостерігаються в країнах 3 доходом, вищим за середній, та в країнах з високим доходом. Отже розрив у розвитку країн за рівнем доходів добре корелюється зі структурою зайнятості на підприємствах за розміром та, відповідно, за ресурсами капіталу, якістю робочих місць, якістю трудового потенціалу.

Співставлення внесків малих, середніх та великих підприємств у зайнятість та у додану вартість в межах світової економіки у 2014 р. та 2019 р., наведених в таблиці 3, показує тенденцію зростання відповідних внесків підприємств малого та середнього бізнесу у зайня-

Внесок компаній за розміром у зайнятість та у додану вартість

Таблиця 3 в межах світової економіки у 2014 та у 2019 рр.

\begin{tabular}{|c|c|c|c|c|}
\hline & \multicolumn{2}{|c|}{$\begin{array}{c}\text { Частка малих, середніх та великих } \\
\text { підприємств у зайнятості населення, \% }\end{array}$} & \multicolumn{2}{|c|}{$\begin{array}{c}\text { Частка підприємств у доданій } \\
\text { вартості, \% }\end{array}$} \\
\hline & 2014 & 2019 & 2014 & 2019 \\
\hline Великі & 30,4 & 25,1 & 43,0 & 36,4 \\
\hline Середні & 42,8 & 47,6 & 39,4 & 42,9 \\
\hline Малі & 26,8 & 27,3 & 17,6 & 20,7 \\
\hline
\end{tabular}

Джерело: складено авторами за даними [7] 
тість - 3 69,6\% до 74,9\%, у додану вартість - 3 $57 \%$ до $63,6 \%$, та зменшення відповідних внесків підприємств великого бізнесу за цей період у зайнятість - $330,4 \%$ до $25,1 \%$, у додану вартість - $343 \%$ до 36,4\%. Отже підвищення частки МСБ у додану вартість за 5 років відбувалось більшим темпом (в середньому 1,32\% на рік), аніж підвищення частки МСБ у зайнятість (в середньому 1,06\% на рік).

Висновки. Таким чином, в процесі формування єдиного світового економічного простору відбувається посилення ролі малого і середнього бізнесу, зростання його економічної ефрективності та соціального значення як фрактора рівня і якості життя. В залежності від рівня соціально-економічного розвитку в країнах складається різне співвідношення фрорм МСБ: що меншим $€$ рівень розвитку країни (за середньодушовим доходом), то більша частка самозайнятих, зайнятих у мікро- і малих підприємствах, то нижча еорективність бізнесу і менший його внесок у додану вартість країни.

Також доведено, що чинник макроекономічної стабільності відіграє важливу роль у фрормуванні ринкового середовища, сприятливого для розвитку крупного бізнесу, або для розвитку МСБ - у разі, якщо макроекономічна стабільність $€$ відносно великою (як це показують економіки регіонів Європи, Північної Америки, Східної Азії та Океанії), то кількість та рівень зайнятості у сфрері МСБ значно менший. В інших регіонах, де рівень макроеконо- мічної стабільності нижчий, статистика показує значно більшу кількість МСБ та зайнятого населення у цій сорері.

В умовах постіндустріалізації світової економіки, її інфрорматизації та впровадження цифрових технологій роль сфрери МСБ зростає через її залучення в процес інноваційного розвитку. На фроні скорочення найманої праці на великих підприємствах через автоматизацію і робототизацію виробництва МСБ зростає його функціональна важливість для створення робочих місць і продукування різноманітних цінностей, що усе більше орієнтується на індивідуальні вимоги. Зростає роль МСБ у нарощенні добробуту населення, розвитку трудового потенціалу і економічної активності як окремої особистості, так і суспільства в цілому, що забезпечує можливість сталого економічного і соціального розвитку. Особливого значення МСБ набуло в розвинених державах, які цілеспрямовано створюють сприятливе інституційне середовище для стимулювання економічної активності на внутрішньому ринку з розрахунком на вихід на світовий ринок.

Перспективи подальшихдосліджень пов'язані з дослідженням тенденцій співвідношення формальної і несрормальної складової МСБ, гендерних пропорцій, впливу актуальних оракторів на структуру і динаміку розвитку сектору, досвіду орормування інституційного середовища в розвинених країнах, можливості його застосування в країнах, що розвиваються, тощо.

\section{СПИСОК ВИКОРИСТАНИХ ДЖЕРЕЛ:}

1. Гой І.В., Смелянська Т.П. Підприємництво. Київ, 2019. 368 с.

2. Дахно І., Алієва-Барановська В. Глобальний бізнес. Київ, 2019. 560 с.

3. Педько А. Основи підприємництва і бізнескультури : навчальний посібник. Київ, 2019. 168 с.

4. Шнирков О.О., Руденко І.В. Місце та роль малого бізнесу у міжнародній економічній діяльності. Молодий вчений. 2020. № 11(87). С. 226-231.

5. Офріційний сайт МОП Small matters. Global evidence on the contribution to employment by the self-employed, micro-enterprises and SMEs. Report ILO 2019. 58 c. URL: https://www.ilo.org/wcmsp5/groups/public/---dgreports/--dcomm/---publ/documents/publication/wcms_723282.pdf (дата звернення: 04.12.2021).

6. Офіційний сайт МОП Small But Critical: Global Evidence on the Contribution of Self-Employed, Microenterprise and SMEs to Employment [Executive Summary]. URL: https://www.ilo.org/moscow/informationresources/publications/WCMS_727167/lang--en/index.htm (дата звернення: 04.12.2021).

7. Офіційний сайт МОП Work for a brighter future. Global comission on the future of work. ILO, 2019. $78 \mathrm{c}$. URL: https://www.ilo.org/wcmsp5/groups/public/---dgreports/---cabinet/documents/publication/wcms_662410.pdf (дата звернення: 04.12.2021).

8. Офіційний сайт ВЕФ Global Competitiveness Report 2019. URL: https://www3.weforum.org/docs/WEF_The GlobalCompetitivenessReport2019.pdf (дата звернення: 04.12.2021).

\section{REFERENCES:}

1. Hoi I.V., Smelianska T.P. (2019) Pidpryiemnytstvo [Entrepreneurship]. Kyiv: «Tsentr uchbovoi literatury». (in Ukrainian) 
2. Dakhno I., Aliieva-Baranovska V. (2019) Hlobalnyi biznes [Global business]. Kyiv: «Tsentr uchbovoi literatury». (in Ukrainian)

3. Pedko A. (2019) Osnovy pidpryiemnytstva i bizneskultury: navchalnyi posibnyk [Fundamentals of entrepreneurship and business culture: Tutorial]. Kyiv: «Tsentr uchbovoi literatury». (in Ukrainian)

4. Shnyrkov O.O., Rudenko I.V. (2020) Mistse ta rol maloho biznesu u mizhnarodnii ekonomichnii diialnosti [The place and role of small business in international economic activity]. Molodyi vchenyi - Young scientist, 11(87), 226-231.

5. Ofitsiinyi sait MOP (2019) Small matters. Global evidence on the contribution to employment by the self-employed, micro-enterprises and SMEs. Available at: https://www.ilo.org/wcmsp5/groups/public/---dgreports/---dcomm/---publ/documents/publication/wcms_723282.pdf (accessed 4 December 2021).

6. Ofitsiinyi sait MOP Small But Critical: Global Evidence on the Contribution of Self-Employed, Microenterprise and SMEs to Employment [Executive Summary]. Available at: https://www.ilo.org/moscow/information-resources/ publications/WCMS_727167/lang--en/index.htm (accessed 4 December 2021).

7. Ofitsiinyi sait MOP (2019) Work for a brighter future. Global comission on the future of work. Available at: https://www.ilo.org/wcmsp5/groups/public/---dgreports/---cabinet/documents/publication/wcms_662410.pdf (accessed 4 December 2021).

8. Ofitsiinyi sait VEF (2019) Global Competitiveness Report Special Edition 2020. Available at: https://www3.weforum.org/docs/WEF_TheGlobalCompetitivenessReport2019.pdf (accessed 4 December 2021). 